Research article

\title{
PREVALENCE AND MOLECULAR CHARACTERIZATION OF ENTEROTOXIN-PRODUCING STRAINS OF STAPHYLOCOCCUS AUREUS ISOLATED FROM SERBIAN DAIRY COWS
}

\author{
PAJIĆ Marija ${ }^{1 *}$, BOBOŠ Stanko ${ }^{1}$, VELEBIT Branko², RAŠIĆ Zoran ${ }^{3}$, KATIĆ Vera ${ }^{4}$, \\ RADINOVIĆ Miodrag ${ }^{1}$, NIKOLIĆ Aleksandra ${ }^{4}$, SIMONOVIĆ Dušan ${ }^{3}$, \\ BABIĆ Milijana ${ }^{4}$
}

\begin{abstract}
${ }^{1}$ Department of Veterinary Medicine, Faculty of Agriculture, University of Novi Sad, Novi Sad, Republic of Serbia; ${ }^{2}$ Institute of Meat Hygiene and Technology, Belgrade, Republic of Serbia; ${ }^{3}$ Institute of Veterinary Medicine "Jagodina", Jagodina, Republic of Serbia; ${ }^{4}$ Faculty of Veterinary Medicine, University of Belgrade, Belgrade, Republic of Serbia
\end{abstract}

(Received 15 September 2015; Accepted 29 June 2016)

Staphylococcus aureus is known worldwide as a frequent cause of mastitis in dairy cattle. Due to the production of heath resistant enterotoxins, this pathogen is also a major cause of food poisoning among humans, with symptoms of often severe vomiting and diarrhea. The aim of our study was to determine the prevalence of enterotoxinproducing strains of $S$. aureus originating from samples of cows with subclinical and clinical mastitis in the Republic of Serbia. Furthermore, we analyzed the type of staphylococcal enterotoxin they produce and phylogenetic relatedness among the $S$. aureus isolates recovered from milk in this study. Production of staphylococcal enterotoxins $\mathrm{A}, \mathrm{B}, \mathrm{C}, \mathrm{D}$ and $\mathrm{E}$ was determined by commercial immunoenzyme assay VIDAS ${ }^{\circledR}$ SET2, and presence of corresponding genes encoding enterotoxin synthesis in positive isolates confirmed by Polymerase Chain Reaction. Enterotoxin production was determined in 5 out of $75(6.67 \%)$ isolates of $S$. aureus and all of them produced staphylococcal enterotoxins $C$. After analyzing the nucleotide sequence of the gene encoding the synthesis of staphylococcal protein A, S. aureus isolates were assigned into 2 phylogenetic groups, including 7 clusters. All $S$. aureus isolates with the presence of sec gene formed one cluster even dough they originated from milk samples from different farms.

Key words: S. aureus, mastitis, staphylococcal enterotoxins, phylogenetic relatedness.

\section{INTRODUCTION}

$S$. aureus is commonly found in the environment [1]. It is known worldwide as a frequent cause of mastitis in dairy cattle, sheep and goats [2,3]. Prolonged adaptation of the pathogen to mammary gland tissue results with the postponed induction of

\footnotetext{
*Corresponding author: e-mail: marija_vet@polj.uns.ac.rs
} 
a massive clinical disease. Therefore, it takes a longer period (weeks, months, even 2 years) before once colonized can induce a massive clinical disease. The pathogen has been most frequently isolated from the udder skin at the top of the papilla, especially in areas affected by skin lesions [4]. The most probable source of antibiotic-resistant strains of $S$. aureus are skin debris particles found on the surface of the milking equipment as described by Heckmann et al. [5].

S. aureus is also a major cause of food poisoning among humans, due to the production of heat-resistant enterotoxins, which when consumed cause vomiting and diarrhea [1]. Enterotoxins are low-molecular weight proteins (26900 - $29600 \mathrm{Da})$. Up to now, more than twenty different staphylococcal enterotoxins (SE), including staphylococcal enterotoxin-like proteins (SEl) have been described, from SEA to SEIX. There is no SEF, it is now referred to as toxic shock syndrome toxin 1 . They all share a superantigenic activity, whereas SEA to SEI, SER, SES, and SET have been proved to be emetic [6-9].

Contaminated milk and milk products have been frequently implicated in staphylococcal food poisoning [10]. SEs are heat resistant and hence may be present even when $S$. aureus is not viable [11]. The presence of staphylococcal enterotoxin genes and the production of SEs by $S$. aureus of bovine origin have been reported in numerous studies. Eleven of 94 S. aureus isolates (11.7\%) in BTM from Argentina showed a production of enterotoxins [12]. One hundred nine of 291 S. aureus isolates $(37.5 \%)$ from milk from mastitic cows, BTM, and cheese from Brazil showed production of one or more enterotoxins [13]. Nineteen of 102 S. aureus isolates (18.6\%) recovered from BTM and milk filters from national milk-producing herds in Ireland showed the presence of one or more enterotoxin genes [14]. Conversely, a higher percentage of isolates, $46.9 \%$ of 130 , associated with subclinical bovine mastitis in Turkey showed the presence of one or more enterotoxin genes [15].

Identification of $S$. aureus strains in the form of the species and/or subspecies, as well as on the percentage of base sequence matching of the tested strains, can be done by analyzing the data on the sequenced parts of highly polymorphic spa gene. This gene consists of 2150 base pairs and encodes the synthesis of surface protein (staphylococcal protein A) which has been known as a virulence factor. It binds to IgG via Fc-binding domain which causes reduced phagocytosis.

The aim of our study was to study the prevalence of enterotoxin-producing strains of S. aureus originating from milk samples of cows with subclinical and clinical mastitis in the Republic of Serbia, to determine the type of staphylococcal enterotoxin they produce and to determine the phylogenetic relatedness of respective strains.

\section{MATERIALS AND METHODS}

A total of 371 cows from 46 dairy farms located in two neighboring districts (5001 $\mathrm{km}^{2}$ ) in Central Serbia ( $1 \%$ of all cows registered in both districts) during one- 
year period (April-October 2012) were tested using California Mastitis Test (CMT) according to the manufacturer's instruction (DeLaval, Sweden). At 34 dairy farms $(73,91 \%)$ herd size ranged from 1 to 5 cows. Milk samples were taken from 111 CMTpositive quarters. Also, 13 samples were taken from cows with clinical mastitis from 2 large farms in Vojvodina province to be used for testing of phylogenetic relatedness.

Samples were immediately dispatched to the laboratory and held in cold chain $\left(3 \pm 2^{\circ} \mathrm{C}\right)$. Prior to analysis, samples were held for 30 minutes at room temperature and afterward homogenized at $2400 \mathrm{rpm}$ for $30 \mathrm{~s}$ (Heidolph Vortex Shaker REAX 1, Germany). Samples $(0,1 \mathrm{~mL}$ each) were plated onto blood agar plates and incubated for 24 to 48 hours at $37^{\circ} \mathrm{C}$. Grown colonies, typical for $S$. aureus (golden-yellow colored, round, convex, and 1-4 mm in diameter with a sharp border, surrounded by zones of clear betahemolysis), were subsequently streaked onto Baird-Parker agar and further confirmed as described in ISO 6888-1:1999. Phenotypical confirmation has been done by using API Staph (bioMérieux, France) and genotyped by PCR targeting nuclease gene and staphylococcal protein A gene - both specific for $S$. aureus. Presence of SEA; SEB; SEC; SED and SEE was determined by VIDAS Set2 (bioMérieux, France). Extraction of SE from the cultures grown overnight in Brain Heart Infusion (BHI) broth (Oxoid, Basingstoke, $\mathrm{UK}$ ) at $37^{\circ} \mathrm{C}$ has been performed according to the European screening method of the EU-CRL-CPS for "coagulase positive staphylococci, including $S$. aureus" [16]. Culture collection strains (Microbiologics, USA) used as positive controls in the study included: S. aureus ATCC 13565 (sea), S. aureus ATCC 14458 (seb), S. aureus ATCC 19095 (sec), S. aureus ATCC 23235 (sed) and S. aureus ATCC 27664 (see).

\section{DNA Extraction}

Bacterial DNA was extracted from a single $S$. aureus colony using $25 \mu \mathrm{L}$ of nucleasefree water and $25 \mu \mathrm{L}$ of PrepMan Ultra reagent (Applied Biosystems, Foster City CA, USA) placed in a $1.5 \mathrm{~mL}$ micro centrifuge tube. The samples were heated in boiling water for 10 minutes, allowed to cool to room temperature and centrifuged at 16000 $\times \mathrm{g}$ for $2 \mathrm{~min}$. The supernatant (containing the DNA) was transferred to a clean 1.5 $\mathrm{mL}$ microcentrifuge tube.

\section{PCR-based detection of the nuclease gene and spa gene}

Details on the primer sequences and expected amplified products are presented in Table 1.

Conventional PCR amplification was performed using a PCR kit (Invitrogen, Carlsbad, CA, USA) in a total volume of $50 \mu \mathrm{L}$ containing $5 \mu \mathrm{L}$ of $10 \times$ reaction buffer, $1 \mu \mathrm{L}$ of dNTPs, $5 \mu \mathrm{L}$ of each primer (Invitrogen, Carlsbad, CA, USA), $1 \mu \mathrm{L}$ of template DNA, $0.25 \mu \mathrm{L}$ of Taq DNA $(5 \mathrm{U} / \mu \mathrm{L})$ and $22.75 \mu \mathrm{L}$ of PCR water to make up the final volume. Amplification was performed using an AB 2720 thermocycler (Applied Biosystems, CA, USA). Thermal cycling conditions were as follows: initial denaturation at $95^{\circ} \mathrm{C}$ for 5 min., followed by 30 cycles of $95^{\circ} \mathrm{C}$ for $30 \mathrm{~s}, 55^{\circ} \mathrm{C}$ for $30 \mathrm{~s}$, and $72^{\circ} \mathrm{C}$ for 
$60 \mathrm{~s}$ with a final extension at $72^{\circ} \mathrm{C}$ for $5 \mathrm{~min}$. Amplification products were separated in a $1.5 \%$ agarose gel stained with ethidium bromide (Sigma, Steinheim, Germany). Electrophoresis was performed for $30 \mathrm{~min}$ at a field strength of $5 \mathrm{~V} / \mathrm{cm}$. Visualization was carried out by the UV transluminator and the Capt Document System (Vilbert Lourmat, France).

Table 1. Primer sequences of nuclease and SPA genes

\begin{tabular}{llcc}
\hline Primer & Primer sequence & $\begin{array}{c}\text { Expected } \\
\text { amplicon size (bp) }\end{array}$ & References \\
\hline $\begin{array}{lll}\text { nuc-f } \\
\text { nuc-r }\end{array}$ & 5'-TCAGCAAATGCATCACAAACAG -3' & 255 & [17] \\
spa-f & 5'- TAAAAAAATGCACTTGCTTCAGG -3' & & \\
$s p a-\mathrm{r}$ & 5'-CAGCAGTAGTGCCGTTTGCTT -3' & $180-600$ & {$[17]$} \\
\hline
\end{tabular}

\section{Real Time PCR-based detection of the SE genes}

Details on primer sequences and expected amplified products are presented in Table 2.

Table 2. Primer sequences of SE genes

\begin{tabular}{|c|c|c|c|}
\hline $\begin{array}{l}\text { sea }-\mathrm{f} \\
\text { sea }-\mathrm{r}\end{array}$ & $\begin{array}{l}\text { 5'-TCAATTTATGGCTAGACGGTAAACAA-3' } \\
\text { 5'-GAAGATCCAACTCCTGAACAGTTACA-3' }\end{array}$ & 93 & [18] \\
\hline $\begin{array}{l}s e b-\mathrm{f} \\
s e b-\mathrm{r}\end{array}$ & $\begin{array}{l}\text { 5'-AАCAACTCGCCTTATGAAACGGGAT-3' } \\
\text { 5'-СТCСTGGTGCAGGCATCATGTCA-3' }\end{array}$ & 85 & This study \\
\hline $\begin{array}{l}\sec -\mathrm{f} \\
\sec _{s}-\mathrm{r}\end{array}$ & $\begin{array}{l}\text { 5'-CGTATTAGCAGAGAGCCAACCA-3' } \\
\text { 5'-GTGAATT'TACTCGCT'TTGTGCAA-3' }\end{array}$ & 225 & [19] \\
\hline $\begin{array}{l}\text { sed }-\mathrm{f} \\
\text { sed }-\mathrm{r}\end{array}$ & $\begin{array}{l}\text { 5'-AAACGTTAAAGCCAATGAAAACA-3' } \\
\text { 5'-TGATCTCCTGTACT'TTTAT'T'TCTCCTA-3' }\end{array}$ & 150 & [18] \\
\hline $\begin{array}{l}s e e-\mathrm{f} \\
s e e-\mathrm{r}\end{array}$ & $\begin{array}{l}\text { 5'-TACCAAT'TAACT'TGTGGATAGAC-3' } \\
\text { 5'-CTCT'T'TGCACC'TTACCGC-3' }\end{array}$ & 171 & [20] \\
\hline
\end{tabular}

Real Time PCR amplification was performed using a Brilliant III Ultra-Fast SYBR Green QPCR Master Mix kit (Agilent Technologies, USA) in a total volume of 50 $\mu \mathrm{L}$ containing $400 \mathrm{nM}$ each of primers and $2 \mu \mathrm{L}$ of DNA sample. Amplification was performed using a MX3005P Real Time PCR machine (Agilent Technologies, USA). Thermal cycling conditions were as follows: initial denaturation at $95^{\circ} \mathrm{C}$ for 3 min., followed by 40 cycles of $95^{\circ} \mathrm{C}$ for $10 \mathrm{~s}$ and $60^{\circ} \mathrm{C}$ for $20 \mathrm{~s}$. 


\section{Determination of phylogenetic relatedness among tested strains of $S$. aureus}

DNA sequence encoding synthesis of staphylococcal protein A (SPA) was used for the determination of phylogenic relatedness of $S$. aureus strains originating from cow's udder with a disturbed secretion. Sequencing was carried out from $20 \mu \mathrm{L}$ of purified SPA amplicon using One Shot Read MP technique. Results were presented in the form of chromatogram and files in FASTA format. For identification of isolates, FASTA format files were loaded in the BLAST (Basic Local Alignment Search Tool) software and the algorithm for recognition of highly similar sequences in microorganisms was selected.

In order to investigate the phylogenic relatedness of the strains, their nucleotide sequences were arranged and aligned using software tool ClustalW Omega Multiple Sequence Alignment (The European Bioinformatics Institute). Phylogenetic analysis was examined for each sequence using the "parsimony" software package (MABL) with 1000 bootstraps and using "neighbor-joining" algorithm. To examine the possibilities of mutual sequence combining, Templeton nonparametric Wilcoxon Signed Rank test was used.

Horizontal lines on the tree indicate the amount of evolutionary genetic changes for each isolate over time. As the line is longer, the genetic changes are more expressed. Length of the line below the phylogram indicates the scalar value of changes, in this case 0.01 or $1 \%$ genetic changes. Genetic changes refer to the number of substituted nucleotides in each sequence. Vertical lines are of no importance; they only visually connect the horizontal lines [21-26].

After completion of the molecular-biological identification, nucleotide sequences encoding staphylococcal protein A of isolates of $S$. aureus originating from cows in our research are deposited in the public database GenBank under accession numbers from KJ023978 to KJ024046 at the US National Center for Biotechnology Information.

\section{RESULTS}

Out of 371 cows tested in two districts in Central Serbia, 111 of them were proved to be CMT-positive $(29,92 \%)$. Using standard microbiological methods, API Staph and PCR (confirmation using nuc and spa genes) a total of 62 isolates of $S$. aureus were recovered from 111 CMT-positive milk samples (55,85\%). Additionally, 13 isolates originating from cows with clinical mastitis from farms in Vojvodina province were also recovered.

A total of 5 enterotoxin-producing isolates have been confirmed among 62 isolates of S. aureus, and all of them produced SEC only (Figure 1), while sea, seb, sed and see genes were not detected. All of this 5 isolates originated from cows with subclinical mastitis. Analyzing the nucleotide sequences of the genes for the synthesis of staphylococcal protein A, S. aureus isolates were phylogenetically grouped into 2 groups, including 7 clusters (Figure 2 and Table 3). 


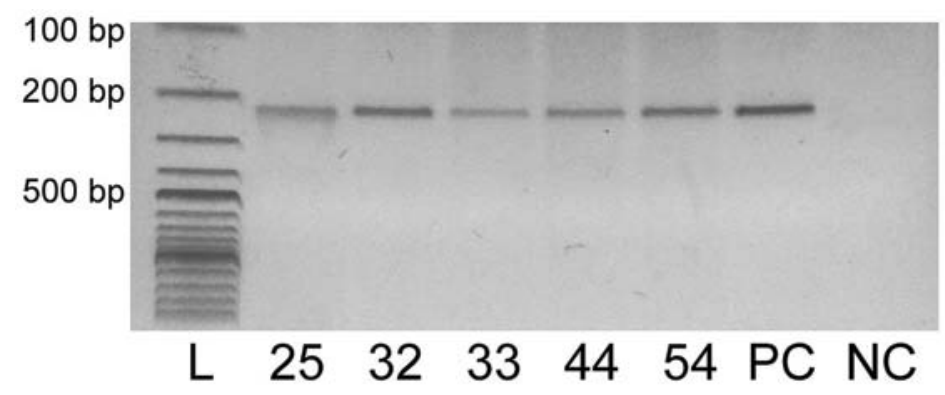

Figure 1. Agarose gel electrophoresis of QPCR amplicon 225 bp SEC amplicons, lane L- 100 bp ladder, lane 25; 32; 33; 44; 54 - isolates, lane PC-ATCC 19095 S. aureus SEC positive, lane NC-negative control

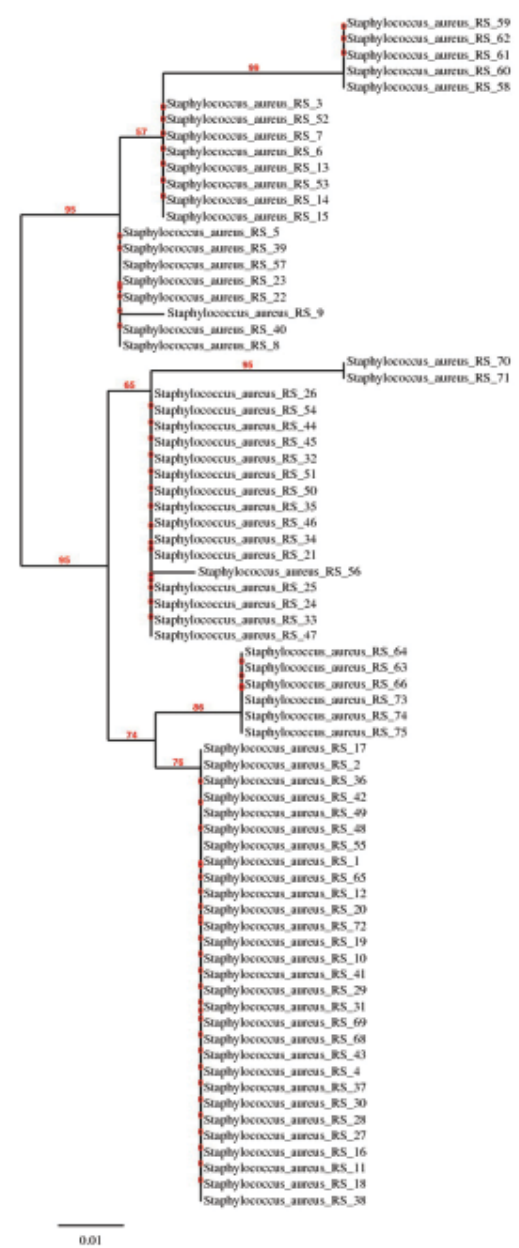

Figure 2. Phylogram based on the sequencing of spa gene of $S$. aureus isolates from dairy cows in cases of subclinical and clinical mastitis, using the "neighbor-joining" analysis and 1000 bootstraps 
Table 3. Groups and clusters of Staphylococcus aureus isolates based on SPA phylogenetic analysis

\begin{tabular}{ccc}
\hline Group & Cluster & Isolates of Staphylococcus aureus labeled by numbers \\
\hline \multirow{2}{*}{1} & 1 & $58,59,60,61,62$ \\
& 2 & $3,6,7,13,14,15,52,53$ \\
& 3 & $5,8,9,22,23,39,40,57$ \\
& 4 & 70,71 \\
\hline & 5 & $21,24,25,26,32,33,34,35,44,45,46,47,50,51,54,56$ \\
& 6 & $63,64,66,73,74,75$ \\
& 7 & $1,2,4,10,11,12,16,17,18,19,20,27,28,2930,31,36,37,38,41,42,43$, \\
$48,49,55,65,68,69,72$
\end{tabular}

\section{DISCUSSION}

S. aureus was isolated from 62 (55.85\%) of 111 milk samples taken from CMT-positive cows which had no clinical symptoms of mastitis. These results are somewhat higher than results of Vieira da Motta from 2001, who isolated 35\% strains of S. aureus from milk samples of CMT-positive cows [27], and Jánosi and Baltay from 2004 who isolated $32.5 \%$ [28]. However, our results correspond to the conclusions of Fox and Gay, who reported S. aureus infection in 7 to $40 \%$ of all cows, not only CMT positive [29].

In our research, all isolates were tested on their ability to synthesize enterotoxins SEA; SEB; SEC; SED and SEE. Enterotoxin-production was determined in $5(6.67 \%)$ isolates of $S$. aureus. Subsequent detection of respective SE-gene(s) discovered sec gene only in all 5 strains. It is worthwhile mentioning that these isolates originated from cows with subclinical mastitis.

Such low prevalence of SE-positive clinical isolates does not correlate with findings reported by other authors. From seven regions of Norway, from different farms, isolates of S. aureus, collected between August and October in 2001, were tested for staphylococcal enterotoxin production (SEA-SED) by reversed passive latex agglutination and for SE genes (sea-see, seg-sej) by multiplex PCR. S. aureus was detected in $75 \%$ bulk milk samples. Enterotoxin production was observed in $22.1 \%$ of $S$. aureus isolates, while SE genes were detected in $52.5 \%$ of the bulk milk isolates [30]. In a study of Adwan et al. in the north of Palestine, in 2005, between February and April, a total of 130 raw milk samples were taken from Fresian cows. None of these animals were diagnosed with clinical mastitis. S. aureus was isolated from 48 $(37 \%)$ milk samples. Enterotoxin genes (sea-see) in $S$. aureus isolates were determined using a polymerase chain reaction (PCR). Out of 48 S. aureus isolates, 14 (29\%) were toxin gene positive, which means that almost $11 \%$ of total milk samples taken were toxin gene positive [31]. Gücükoglu et al. published in 2012 results of a study on the prevalence of enterotoxigenic $S$. aureus isolated from raw milk samples in Samsun 
province in Turkey. In their study, $S$. aureus was detected in 45 of 60 raw milk samples (75\%). Using multiplex PCR they had determined the presence of genes for the synthesis of staphylococcal enterotoxins SEA, SEB, SEC, and SED, in 13.7\% isolates from raw milk samples [32].

Our results are in agreement with the results obtained in all over Europe that SECs are the most common SE of $S$. aureus strains isolated from cow's udder, however, in France, bovine strains of $S$. aureus are more often SED producers [33].

With the discovery of new enterotoxins other than SEA to SEE, the observed percentage of potentially enterotoxigenic $S$. aureus strains increased. In our study only genes encoding the classical enterotoxins were identified. Rall et al. [34] found that $68.4 \%$ out of 57 strains isolated from raw or pasteurised bovine milk were positive for the presence of at least one SE gene, however the number dropped down to $52.5 \%$ when only the classical enterotoxins (SEA - SEE) were considered. Similar observations were made by Rosec and Gigaud [35], who detected 30\% of the isolates with the genes encoding classical enterotoxins, but that frequency has increased to $57 \%$ when the new SE's were taken into account. Other authors observed that $S$. aureus strains isolated from animals produce mainly SEC, whereas among strains isolated from humans, SEA was most frequently identified [36-38]. In agreement with these results, in our study the gene encoding staphylococcal enterotoxin $C$ was the most often observed. In spite of discrepancies in data concerning the prevalence of enterotoxigenic $S$. aureus isolated from different types of food, our study also confirmed, that SEC are the most often observed toxins in enterotoxigenic strains of $S$. aureus in bovine milk.

Still, the possibility of subsequent contamination of milk products should not be ignored. It can be supported by the fact which type of SE is determined in milk products. For example, in Teheran, in 2010, $32 \mathrm{~S}$. aureus were determined from dairy products: 18 from cream, 10 from cheese, and 4 from milk. Both of SEA and SEB genes were detected by multiplex PCR and results were compared with the phenotypic method [39].

In our research, phylogenetic relatedness was determined by analyzing the nucleotide sequences of the genes for the synthesis of staphylococcal protein A. All isolates of $S$. aureus in which the gene for enterotoxin synthesis has been determined belonged to the same cluster - cluster 5 , although they originated from 4 different farms. They also had identical all of the 25 tested biochemical characteristics and they originated from cows with no clinical symptoms of mastitis. Of the spa types obtained in our study, four of the $S$. aureus isolates belonged to the type found in Croatia [40], t005, while one isolate belonged to type $\mathrm{t} 011$, which is common throughout France, Belgium, Germany, Switzerland, and the United States (http://www.spaserver.ridom.de).

One should be aware that predominance of cluster No. 5 might simply result from specificity related to relatively narrow geographical distribution and moving dairy cows among different farm traders. 


\section{Acknowledgement}

Funding for this research was provided through project of the Ministry of Education, Science and Technological Development, Republic of Serbia, project TR 31034

The authors wish to acknowledge the help of the Institute of Meat Hygiene and Technology in Belgrade, the Institute of Veterinary Medicine "Jagodina" in Jagodina and the Scientific Veterinary Institute "Novi Sad" in Novi Sad for their technical support.

\section{Authors' contributions}

MP defined the research theme, gave conception of the research. SB, BV and ZR participated in the design of the research. BV carried out the molecular genetic studies. ZR, MR, MB, AN and DS have made contributions to acquisition of isolates of Staphylococcus aureus from cow's udder with subclinical mastitis and from cow's udder with clinical mastitis. MP, SB, BV, ZR and VK worked on analysis and interpretation of results and gave the final version of manuscript. All authors have read and approved the final manuscript.

\section{Declaration of conflicting interests}

The author(s) declared no potential conflicts of interest with respect to the research, authorship, and/or publication of this article.

\section{REFERENCES}

1. ICMSF (1996) S. aureus. In: Roberts TA, Baird-Parker AC Tompkin RB (Eds.) Microorganisms in foods 5. Characteristics of microbial pathogens. Blackie Academic and Professional, London; 1996.

2. Stewart GC: S. aureus. In: Fratamico PM, Bhunia AK, Smith JL (Eds) Foodborne pathogens: Microbiology and molecular biology. Caister Academic Press, Norfolk; 2005.

3. Rajić Savić N, Katić V, Velebit B: Characteristics of coagulase positive staphylococci isolated from milk in cases of subclinical mastitis. Acta Vet-Belgrade 2014, 64(1):115-123.

4. Boboš S, Vidić B: Mammary gland of ruminant's pathomorfology (in Serbian). Monography, Poljoprivredni fakultet Novi Sad, Naučni Institut za veterinarstvo "Novi Sad”, Serbia, Novi Sad; 2005.

5. Heckmann RA: Quality control and evaluation of milking machine liners (inflations) and milk tubes using scanning electron microscopy and X-ray microanalysis. Microscopy and Analysis 1997, 17:35-37.

6. Le Loir Y, Baron F, Gautier M: S. aureus and food poisoning. Genet Mol Res 2003, 2(1):6376.

7. Hu DL, Nakane A: Mechanisms of staphylococcal enterotoxin-induced emesis. Eur J Pharmacol 2014, Jan 5; 722:95-107. 
8. Omoe K, Hu DL, Ono HK, Shimizu S, Takahashi-Omoe H, Nakane A, Uchiyama T, Shinagawa K, Imanishi K: Emetic potentials of newly identified staphylococcal enterotoxinlike toxins. Infect Immun 2013, Oct; 81(10):3627-31.

9. Dinges MM, Orwin PM, Schlievert PM: Exotoxins of S. aureus. Clin Microbiol Rev 2000, 13(1):16-34.

10. De Buyser ML, Dufour B, Maire M, Lafarge V: Implication of milk and milk products in food-borne diseases in France and in different industrialised countries. Int. J. Food Microbiol. 2001, 67:1-17.

11. Peles F, et al. Characterization of Staphylococcus aureus strains isolated from bovine milk in Hungary. Int. J. Food Microbiol. 2007, 118:186-193.

12. Neder VE, Canavesio VR, Calvinho LF: Presence of enterotoxigenic Staphylococcus aureus in bulk tank milk from Argentine dairy farms. Rev. Argent. Microbiol. 2011, 43:104 106.

13. Arcuri EF, et al. Toxigenic status of Staphylococcus aureus isolated from bovine raw milk and Minas frescal cheese in Brazil. J. Food Prot. 2010, 73:2225-2231.

14. Murphy BP, O’Mahony E, Buckley JF, O’Brien S, Fanning S. Characterization of Staphylococcus aureus isolated from dairy animals in Ireland. Zoonoses Public Health 2010, 57:249-257.

15. Hata E, et al. Genetic variation among Staphylococcus aureus strains from bovine milk and their relevance to methicillin-resistant isolates from humans. J. Clin. Microbiol. 2010, 48:2130-2139.

16. Ostyn A, Prufer AL, Papinaud I, Hennekinne JA, Assere A, Lombard B: European screening method of the EU-CRL-CPS for "coagulase positive staphylococci, including $S$. aureus". Version 5, 2010.

17. Anon. Protocol Multiplex PCR for the detection of the mecA gene. National Food Institute, Technical University Denmark 2008 [http://www.crl-ar.eu/data/images/mecapcr_protocol\%2006.02.08.pdf]

18. Duquenne M, Fleurot I, Aigle M, Darrigo C, Borezée-Durant E, Derzelle S, Bouix M, Deperrois-Lafarge V, Delacroix-Buchet A: Tool for quantification of staphylococcal enterotoxin gene expression in cheese. Appl Environ Microbiol 2010, 76:1367-1374.

19. Shannon KE, Lee DY, Trevors JT, Beaudette LA: Application of real-time quantitative PCR for the detection of selected bacterial pathogens during municipal wastewater treatment. Sci. Total Environ 2007, 382:121-129.

20. Monday SR, Bohach GA: Use of multiplex PCR to detect classical and newly described pyrogenic toxin genes in staphylococcal isolates. J Clin Microbiol 1999, 37:3411-3414.

21. Dereeper A, Audic S, Claverie JM, Blanc G. BLAST-EXPLORER helps you building datasets for phylogenetic analysis. BMC Evol Biol 2010, 10:8.

22. Dereeper, Alexis, et al. "Phylogeny. fr: robust phylogenetic analysis for the nonspecialist." Nucleic acids research 36, suppl 2, 2008: W465-W469.

23. Edgar RC. MUSCLE: multiple sequence alignment with high accuracy and high throughput. Nucleic Acids Res 2004, 32:1792-1797.

24. Castresana J. Selection of conserved blocks from multiple alignments for their use in phylogenetic analysis. Mol Biol Evol 2000, 17:540-552.

25. Guindon S, Gascuel O. A simple, fast, and accurate algorithm to estimate large phylogenies by maximum likelihood. Syst Biol 2003, 52:696-704. 
26. Anisimova M, Gascuel O. Approximate likelihood ratio test for branchs: A fast, accurate and powerful alternative. Syst Biol 2006, 55:539-552.

27. Vieira-da-Motta O, Folly MM, Sayiama CCH: Detection of different $S$. aureus strains in bovine milk from subclinical mastitis using PCR and routine techniques. Braz J Microbiol 2001, 32:27-31.

28. Jánosi S, Baltay Z: Correlations among the somatic cell count of individual bulk milk, result of the California Mastitis Test and bacteriological status of the udder in dairy cows. Acta Vet Hung 2004, 52:173-183.

29. Fox LK, Gay JM: Contagious mastitis. Vet Clin North Am Food Anim Pract 1993, 9:475-487.

30. Jorgensen HJ, Mork T, Hogasen HR, Rorvik LM: Enterotoxigenic S. aureus in bulk milk in Norway. J Appl Microbiol 2005, 99:158-166.

31. Adwan G, Abu-Shanab B. Adwan K: Enterotoxigenic $S$. aureus in raw milk in the North of Palestine. Turkish J Biol 2005, 29:229-232.

32. Gücükoğlu A, Kevenk TO, Uyanik T, Cadirci O, Terzi G, Alişarli M, Detection of enterotoxigenic $S$. aureus in raw milk and dairy products by multiplex PCR. J Food Sci 2012, 77:620-623.

33. Ostyn A, De Buyser M-L, Guillier F, Krys S, Hennekinne J-A: Benefits of the combined use of immunological and PCR based methods for determination of staphylococcal enterotoxins food safety criteria in cheeses. Food Anal Method 2011, 5:173-178.

34. Rall VLM, Vieira FP, Rall R, Vieitis RL, Fernandes Jr. A, Candeias JMG, Cardoso KFG, Araujo Jr. JP: PCR detection of staphylococcal enterotoxin genes in Staphylococcus aureus strains isolated from raw and pasteurized milk. Vet Microbiol 2008, 132, 408-413.

35. Rosec JP, Gigaud O: Staphylococcal enterotoxin genes of classical and new types detected by PCR in France. Int J Food Microbiol 2002, 77, 61-70.

36. Bergdoll MS: Staphylococcal food poisoning. In:Foodborne Diseases. Edited by Cliver DO, Academic Press, San Diego, USA, 1990, pp. 85-106.

37. da Silva ER, do Carmo LS, da Silva N: Detection of enterotoxins A, B and C genes in Staphylococcus aureus from goat and bovine mastitis in Brazilian dairy herds. Vet Microbiol 2005, 106, 103-107.

38. Orden JA, Goyache J, Hernandez J, Domenech A, Suarez G, Gomez-Lucia E: Detection of enterotoxins and TSST-1 secreted by Staphylococcus aureus isolated from ruminant mastitis. Comparison of ELISA and immunoblot. J Appl Bacteriol 1992, 28, 947-950.

39. Imani Fooladi AA, Tavakoli HR, Naderi A: Detection of enterotoxigenic $S$. aureus isolates in domestic dairy products. Iran J Microbiol 2010, 2:137-142.

40. Jaki Tkalec V, Majnarić D, Jurmanović J, Habrun B, Cvetnić Ž, Zadravec M, Šeol Martinec B: Meticilin-rezistentni Staphylococcus aureus kod krava s mastitisom, prisutnost mecA gena i gena za virulenciju. Mljekarstvo 2015, 65(4):259-268. 


\title{
PREVALENCIJA I MOLEKULARNA KARAKTERIZACIJA ENTEROTOKSIN-PRODUKUJUĆIH SOJEVA $S$. AUREUS IZOLOVANIH IZ VIMENA KRAVA U SRBIJI
}

\author{
PAJIĆ Marija, BOBOŠ Stanko, VELEBIT Branko, RAŠIĆ Zoran, KATIĆ Vera, \\ RADINOVIĆ Miodrag, NIKOLIĆ Aleksandra, SIMONOVIĆ Dušan, \\ BABIĆ Milijana
}

Širom sveta $S$. aureus poznat je kao čest uzročnik mastitisa krava. Takođe predstavlja i glavni uzrok trovanja hranom nakon konzumiranja hrane kontaminirane njegovim enterotoksinima. Cilj ovog istraživanja bio je da se ispita prevalencija enterotoksinprodukujućih sojeva $S$. aureus poreklom iz vimena krava sa subkliničkim i kliničkim mastitisom u Srbiji, da se odredi tip enterotoksina koji produkuju i da se odredi filogenetska srodnost ovih izolata. Za odredivanje sposobnosti sinteze stafilokoknih enterotoksina A, B, C, D i E korišćen je VIDAS® SET2 immunoenzimski test i utvrđeno je da 5 od $75(6,67 \%)$ izolata $S$. aureus sintetiše enterotoksine. Lančanom reakcijom polimeraze na prisustvo odgovarajućih gena, utvrđeno je da svih 5 izolata poseduju gen za sintezu enterotoksina C. Analizom nukleotidnih sekvenci gena za sintezu stafilokoknog proteina A, izolati $S$. aureus grupisani su filogenetski u 2 grupe, odnosno u 7 klastera. Svi izolati S. aureus kod kojih je dokazano prisustvo gena za sintezu enterotoksina spadaju u isti klaster. 